\title{
Crg, a Gene Required for Ur-3-Mediated Rust Resistance in Common Bean, Maps to a Resistance Gene Analog Cluster
}

\author{
V. Kalavacharla, ${ }^{1}$ J. R. Stavely, ${ }^{2}$ J. R. Myers, ${ }^{3}$ and P. E. McClean ${ }^{1}$ \\ ${ }^{1}$ Department of Plant Sciences, Loftsgard Hall, North Dakota State University, Fargo 58105, U.S.A.; ${ }^{2}$ USDA- \\ ARS, Molecular Plant Pathology Laboratory, PSI, 10300 Baltimore Avenue, Beltsville, MD 20705-2350, \\ U.S.A.; ${ }^{3}$ Department of Horticulture, Oregon State University, Corvallis 97331-7304, U.S.A. \\ Accepted 20 July 2000.
}

Race-specific resistance to the bean rust pathogen (Uromyces appendiculatus) is provided by a number of loci in common bean (Phaseolus vulgaris). The Ur-3 locus controls hypersensitive resistance (HR) to 44 of the 89 races curated in the United States. To better understand resistance mediated by this locus, we developed new genetic material for analysis. We developed a population of mutagenized seed of cv. Sierra (genotype $=U r-3$ ur-4 ur-6) that was screened with a bean rust race that is normally incompatible (HR response) on $\boldsymbol{U r}-3$ genotypes. We discovered two mutants of common bean, crg and ur3- $\Delta 3$, in which uredinia formed on leaves (a compatible interaction) following infection. The $F_{1}$ generation from a cross of these two mutants expressed the $H R$ response, and the $F_{2}$ generation segregated in a ratio of 9:7 (HR/uredinia formation). Therefore, the two genes are unlinked. Further genetic analysis determined that the mutation in ur3- $\Delta 3$ was in the $U r$-3 locus, and the mutation in crg was in a newly discovered gene given the symbol $\mathrm{Crg}$ (Complements resistance gene). Each mutation was inherited in a recessive manner. Unlike ur $3-\Delta 3$, crg expressed reduced compatibility to bean rust races 49 and 47 that are normally fully compatible on genotypes, such as Sierra, that are homozygous recessive at the $U r-4$ and $U r-6$ loci. This suggests a gene mutated in crg is normally a positive compatibility factor for the bean-bean rust interaction. Polymerase chain reaction analysis of crg with primers to common bean resistance gene analogs (RGA) that contain a nucleotide-binding site sequence similar to those found in a number of plant disease resistance genes revealed that crg is missing the SB1 RGA, but not the linked SB3 and SB5 RGAs. Genetic analyses revealed that Crg cosegregates with the SB1 RGA. These results demonstrate that $\mathrm{Crg}$ is located near a RGA cluster in the common bean genome.

Race-specific resistance to many plant pathogens is mediated by plant resistance $(R)$ genes that act in a gene-for-gene manner (Flor 1956). To understand the molecular interactions

Corresponding author: P. E. McClean; E-mail: mcclean@plains.nodak.edu that underlie gene-for-gene resistance, over $20 R$ genes have been cloned and their putative products characterized. Among this large number of genes, however, only six different protein structures were identified that consist of various combinations of kinase, nucleotide-binding site (NBS), and leucine-rich repeat (LRR) domains (Baker et al. 1997).

The interaction between the host $R$ gene and the pathogen avirulence gene activates a wide array of host resistance physiological responses (Hammond-Kosack and Jones 1996). It is now becoming clear that an array of complementary genes act as intermediaries in a signal transduction pathway between the $R$ gene and the genes responsible for the physiological defense response. The existence of these genes was suggested by early genetic studies like those in oat, where it was discovered that the cv. Bond carried two unlinked genes required for resistance to crown rust race 1 (Hayes et al. 1939), and the cv. Victoria carried a third race 1 resistance gene (Weetman 1942). Kehr and Hayes (1950) subsequently discovered a fourth gene from cv. Landhafer that conferred resistance to the same race. Although these studies revealed the existence of complementary genes, they were not designed to distinguish the $R$ gene from a complementary gene in a $R$ gene-mediated resistance pathway.

More recently, genetic analyses of mutants that express increased compatibility to normally avirulent pathogens have defined specific complementary genes that encode signal transduction components of $R$ gene-mediated resistance pathways. These genes include $\operatorname{Prf}$ (Salmeron et al. 1994) and Rer-1 and Rcr-2 (Hammond-Kosack et al. 1994) in tomato; NDRl (Century et al. 1995), EDS (Parker et al. 1996), PAD4 (Glazebrook et al. 1997), and PBS1 and PBS2 (Warren et al. 1999) in Arabidopsis; and Rarl and Rar2 (Jøregensen 1988; Torp and Jøregensen 1986) in barley. In addition, two barley genes involved in non-race-specific resistance, Ror 1 and Ror2, were discovered using these approaches (Freialdenhoven et al. 1996). These complementary resistance genes encode a variety of proteins including a lipase (EDSI) (Falk et al. 1999), a zinc-binding protein (Rar 1) (Carrington et al. 1999), and a membrane-associated protein product of unknown function (NDRl) (Century et al. 1997). Prf represents a unique signal transduction gene because it encodes a leucine zipper (LZ)-NBS-LRR protein similar to some $R$ genes (Salmeron et al. 1996). Interest- 
ingly, this LRR protein is required by Pto, the only nonLRR $R$ gene, for expression of the resistance response (Salmeron et al. 1994).

We are investigating disease resistance in common bean by studying the genetics and molecular components required for bean rust resistance. The bean rust pathogen, Uromyces appendiculatus, is one of the most variable of plant pathogens (Stavely 1984b; Stavely et al. 1989). Eighty-nine distinct races that were collected from various production locations are currently curated in the United States (Stavely 1998). As with many race-specific host-pathogen interactions, the bean-bean rust interaction follows the gene-for-gene model (Christ and Groth 1982). Resistance to the autoecious, biotrophic fungus $U$. appendiculatus is usually provided by dominant-acting genes (Ballantyne 1978; Grafton et al. 1985; Sayler et al. 1995; Stavely 1984a). Of particular interest to our research is the $U r-3$ locus that provides unique resistance to 44 of the 89 bean rust races in the U.S. collection (Stavely 1998). The incorporation of this locus into several recently released common bean cultivars (Stavely et al. 1997) is of economic importance because this locus provides resistance to race 54, the most prevalent bean rust race in the central (Steadman et al. 1996) and upper Midwest (Venette et al. 1998) growing regions of the United States.

Our long-term objective is to identify the molecular components necessary for $U r$-3-mediated bean rust resistance. We are using a combination of mutational analysis and marker development to achieve these objectives. Here, we describe our mutagenesis experiments, which identified one mutant at the classic $U r-3$ locus and a second mutant that defines a new gene, $\mathrm{Crg}$ (complements resistance gene), that complements $U r-3$ hypersensitive resistance. We also applied our collection of common bean resistance gene analog (RGA) sequences (Rivkin et al. 1999) and demonstrated that $\mathrm{Crg}$ is located in a chromosomal region that contains a cluster of RGAs.

\section{RESULTS}

\section{Identification of bean rust-susceptible mutants.}

To better understand the genetic mechanisms controlling bean rust resistance in common bean, we used mutagenesis to create novel genetic material that expresses a loss of the hypersensitive resistance (HR) response. A total of 24,000 progeny of fast-neutron-treated cv. Sierra $(U r-3)$ seed, from two seed bulks, were screened with bean rust race 53 . When challenged with this race, Sierra, and other genotypes carrying $U r-3$, exhibit an HR response. One mutant, crg, exhibited primarily grade 4 uredinia (Table 1). From the second seed bulk, two mutants, ur3- $\Delta 2$ and ur3- $\Delta 3$, were discovered that exhibited primarily grade 5 uredinia formation. At least 10 progeny of each mutant were challenged with race 53 and all exhibited the same pathogenic response as the original mutant plant.

Phenotypically, the three susceptible plants were very similar to Sierra. The only distinguishing characteristics were the extensive vegetative growth period and low seed set for ur3$\Delta 2$ and ur3- $\Delta 3$. For these two traits, crg was similar to Sierra. The three mutants were further compared with Sierra using the rapid amplification of polymorphic DNA (RAPD) procedure with 20 random oligonucleotide primers. These primers were chosen because they revealed polymorphism between Sierra and several other common bean cultivars. The RAPD analysis did not distinguish between mutant and Sierra DNA. Collectively, this data suggests that these are susceptible mutants derived from Sierra.

\section{Mutants are distinguished by infection response to six bean rust races.}

The unique infection response of crg suggested that its mutation was distinct from that of ur3- $\Delta 2$ and ur3- $\Delta 3$. The mutants were further characterized by their response to infection by six additional bean rust races. These races were selected because they attack a number of the important bean rust resistance loci. Sierra (genotype $=U r-3$ ur-4 ur-6 ur-11) was included for comparison. Twenty-two individual $\mathbf{M}_{3}$ plants were each simultaneously infected with bean rust races 41,54 , and 108. As expected, Sierra responded to the three $U r-3$ races with the expected grade $2 \mathrm{HR}$ response (Table 1). The response of crg plants to the three $U r-3$ races was similar to its race 53 response: grade 4 uredinia formation. Similarly, the response of mutants ur3- $\Delta 2$ and ur3- $\Delta 3$ to the three races was identical to their response to race 53 : grade 5 uredinia formation.

The same mutant plants were also infected with races for which $U r$-4 (race 49), $U r$-6 (race 47), and $U r-11$ (race 67) provide protection. All three mutants responded with a fully susceptible grade 5 uredinia response to race 67 , a response similar to Sierra. Infecting Sierra and the mutants with races 47 and 49 , however, distinguished $\mathrm{crg}$. In each case, these races developed distinctly larger uredinia on Sierra and mutants ur3$\Delta 2$ and ur3- $\Delta 3$ than on crg (Table 1). As inoculation controls, the bean rust differential cvs. Aurora, Olathe, Mex 235, and 51051 (Stavely et al. 1983) were infected with these seven races, and the expected resistance response was observed for each (Stavely 1984b; Stavely et al. 1989).

Several results lead us to conclude that mutants ur3- $\Delta 2$ and ur3- $\Delta 3$ may be siblings. First, they were derived from the same bulk. Second, their morphology and pathogenic response to the various bean rust races were identical. Third, molecular markers have not been discovered that distinguishes these two mutants. Therefore, at this point, we suspended the genetic analysis of mutant ur3- $\Delta 2$ and concentrated on ur3- $\Delta 3$.

Table 1. Pathogenic response of cv. Sierra and mutants crg, ur3- $\Delta 2$, and ur3 $-\Delta 3$ to infection by seven bean rust races specific to four common bean rust resistance loci $^{\mathrm{a}}$

\begin{tabular}{llllc}
\hline & \multicolumn{4}{c}{ Genotype } \\
\cline { 2 - 5 } Race (locus) & Sierra & crg & ur3- $\Delta \mathbf{2}$ & ur3- $\Delta \mathbf{3}$ \\
\hline $41(U r-3)$ & 2 & $4,3,5$ & $5,6,4$ & $5,4,6$ \\
$53(U r-3)$ & 2 & 4,3 & $5,4,6$ & $5,4,6$ \\
$54(U r-3)$ & 2 & 4,3 & 6,5 & $5,4,6$ \\
$108(U r-3)$ & 2 & $4,3,5$ & $5,4,6$ & $5,4,6$ \\
$49(U r-4)$ & $5,4,6$ & 4,3 & $5,4,6$ & $5,4,6$ \\
$47(U r-6)$ & 6,5 & $4,3,5$ & $5,4,6$ & $5,4,6$ \\
$67(U r-11)$ & $5,6,4$ & $5,6,4$ & $5,4,6$ & $5,4,6$ \\
\hline
\end{tabular}

a Rust uredinia grades: $2=$ chlorotic or necrotic hypersensitive lesions less than 0.3 -mm diameter in size with no sporulation; $3=$ sporulating uredinia less than $0.3 \mathrm{~mm}$ in size; $4=$ sporulating uredinia 0.3 to 0.5 $\mathrm{mm}$ in size; $5=$ sporulating uredinia 0.5 to $0.8 \mathrm{~mm}$ in size; and $6=$ sporulating uredinia greater than $0.8 \mathrm{~mm}$ in size. If a leaf exhibited multiple infections rankings, they are listed in order of most prevalent to least prevalent. 
Mutant crg identifies a new gene

\section{that complements $U r$-3-mediated resistance.}

To determine the genetic nature of mutants crg and ur3- $\Delta 3$, each was crossed to Sierra, their resistant progenitor. For each cross, the $F_{1}$ progeny expressed an HR response to bean rust race 53, and the pathogenic response of $F_{2}$ progeny segregated in a ratio of 3:1 (HR/uredinia formation) (Table 2). This result suggested that the susceptible phenotypes of the two mutants were the result of a single, recessive-acting mutation.

To determine the genetic relationship of the two mutations, crg and ur3- $\Delta 3$ were intermated. When challenged with race $53, F_{1}$ progeny expressed an $\mathrm{HR}$ response. Two $\mathrm{F}_{2}$ families were developed by selfing two $F_{1}$ plants. Because the segregation ratios were identical (data not shown), the data were pooled. Genetic analysis of the $212 \mathrm{~F}_{2}$ plants confirmed that they segregated in a ratio of 9:7 (HR/uredinia formation) $\left(\chi^{2}=\right.$ $0.058 ; P=0.81$ ) (Table 2). This result indicates the gene mutated in crg is different than that mutated in ur3- $\Delta 3$. Furthermore, these two genes are not genetically linked.

Two alternative genetic combinations are possible for the mutations. First, each mutation may identify a different complementary gene required for $U r-3-$ mediated resistance. Alternatively, one mutation may be in the $U r-3$ locus, and the second mutation may be in a gene that complements $U r-3$. To determine which interpretation was correct, each mutant was crossed to Olathe, a ur-3 genotype. All $\mathrm{F}_{2}$ progeny from two crosses of mutant ur3- $\Delta 3 \times$ Olathe were susceptible (Table 2 ). This result indicates that the mutation in ur3- $\Delta 3$ is at the $U r-3$ locus. The progeny of $F_{2}$ families from the cross crg $\times$ Olathe segregated in a ratio of 9:7 (HR/uredinia formation) (Table 2). This result proves that the mutation in crg is not at $U r-3$ but rather in a previously unknown gene that is necessary for $U r$ 3 -mediated resistance. We have given this gene the symbol Crg (Complements resistance gene).

\section{Deletion of common bean RGA SB1 in mutant crg.}

Eight common bean RGAs, based on conserved NBS sequences, were recently cloned from common bean (Rivkin et al. 1999). A number of genes associated with plant disease resistance contain NBS sequences (Baker et al. 1997); therefore, we screened our mutants to determine if any RGA was deleted. DNA from the three mutants was amplified with primers specific to each RGA class (Rivkin et al. 1999), and we discovered that the SB1 amplification product was missing from crg but present in mutants ur3- $\Delta 2$ and ur3- $\Delta 3$ (Fig. 1A).
The appropriate-sized fragment was detected following amplification of DNA of the three mutants with primers to the other seven RGAs. Southern analysis was next performed by hybridizing the insert of the SB1 RGA clone to mutant, Sierra, and Olathe DNAs. The hybridization pattern for mutant ur3$\Delta 3$ was identical to Sierra, whereas a 2.6-kilobase (kb) HindIII and $6.0-\mathrm{kb}$ EcoRI restriction fragment was missing from digests of crg DNA.

Susceptibility at $U r-3$ and the loss of the SB1 RGA in mutant crg were correlated; therefore, the inheritance of the crg and SB1 was investigated in $F_{1}$ and $F_{2}$ generations from the cross crg $\times$ Sierra. DNA from $F_{1}$ and $F_{2}$ progeny were amplified with SB1-specific primers. The appropriate-sized fragment was present in the $F_{1}$ generation. A polymerase chain reaction (PCR) fragment of the expected size was amplified from DNA of each $\mathrm{F}_{2}$ plant expressing the HR response after race 53 infection and was absent from amplification products of each $\mathrm{F}_{2}$ plant in which uredinia formed (Fig. 1B). Hybridizations using the insert of the SB1 clone as a probe demonstrated that resistant plants contained the appropriate restriction fragments that were absent from susceptible plants (Fig. 1C). This result indicates that SB1 cosegregates with $\mathrm{Crg}-$ mediated resistance.

To further verify this genetic result, the inheritance of the SB1 PCR fragment and $\mathrm{Crg}$ was determined by analyzing the progeny of the cross crg $\times$ ur3- $\Delta 3$. In this cross, $C r g$ and $U r-3$ are both segregating. Both genes are required for the HR response; therefore, each HR-expressing plant would be expected to contain $\mathrm{Crg}$ and the linked SB1 RGA. This result was observed. In addition, some plants expressing uredinia formation following infection would contain $\mathrm{Crg}$ and SB1. This genetic hypothesis would predict the population would segregate in a 9:3:4 ratio (HR and SB1 present to uredinia formation/SB1 present to uredinia formation/SB1 absent). Analysis of the data demonstrates that the population fits this ratio $\left(\chi^{2}=4.46 ; P=0.11\right)$. This result confirms our hypothesis that the SB1 RGA cosegregates with $\mathrm{Crg}$.

\section{DISCUSSION}

To better understand bean rust resistance in common bean, we are increasing our genetic resources by generating new mutations related to the $U r-3-$ mediated HR response. Our mutagenesis and disease-screening experiments identified three mutants of Sierra (genotype $=U r-3$ ) that each express uredinia formation

Table 2. Phenotypic distribution of pathogenic response of $F_{1}$ and $F_{2}$ plants of populations of crosses involving mutants crg and ur3- $\Delta 3$ to Uromyces appendiculatus race 53

\begin{tabular}{|c|c|c|c|c|c|c|}
\hline \multirow[b]{2}{*}{ Cross } & \multicolumn{2}{|c|}{$F_{1}$ pathogenic response } & \multicolumn{2}{|c|}{$F_{2}$ pathogenic response } & \multirow[b]{2}{*}{ Ratio } & \multirow[b]{2}{*}{$P^{\mathbf{c}}$} \\
\hline & HR $^{\mathbf{a}}$ & Uredinia $^{b}$ & HR & Uredinia & & \\
\hline $\operatorname{crg} \times$ cv. Sierra & 5 & $\ldots$ & 74 & 24 & $3: 1$ & 0.91 \\
\hline ur $3-\Delta 3 \times$ Sierra & 2 & $\ldots$ & 44 & 9 & $3: 1$ & 0.18 \\
\hline \multirow{2}{*}{$\operatorname{crg} \times \operatorname{ur} 3-\Delta 3$} & 4 & $\ldots$ & 121 & 91 & $9: 7$ & 0.81 \\
\hline & $\ldots$ & $\ldots$ & $\ldots$ & $\ldots$ & $1: 1$ & 0.04 \\
\hline \multirow[t]{2}{*}{$\operatorname{crg} \times \mathrm{cv}$. Olathe } & $\ldots$ & 6 & 144 & 91 & $9: 7$ & 0.12 \\
\hline & $\ldots$ & $\ldots$ & $\ldots$ & $\ldots$ & $3: 1$ & $>0.0001$ \\
\hline ur3- $\Delta 3 \times$ Olathe & $\ldots$ & 2 & 0 & 71 & $0: 1$ & 1.00 \\
\hline
\end{tabular}

${ }^{a} \mathrm{HR}=$ hypersensitive response; grade $=2$ (chlorotic or necrotic hypersensitive lesions less than 0.3 -mm diameter in size with no sporulation).

${ }^{\mathrm{b}}$ Uredinia $=$ presence of uredinia. Rust uredinia grades: $3=$ sporulating uredinia less than $0.3 \mathrm{~mm}$ in size; $4=$ sporulating uredinia 0.3 to $0.5 \mathrm{~mm}$ in size; $5=$ sporulating uredinia 0.5 to $0.8 \mathrm{~mm}$ in size; and $6=$ sporulating uredinia greater than $0.8 \mathrm{~mm}$ in size.

${ }^{\mathrm{c}}$ Probability from a $\chi^{2}$ test for goodness-of-fit of data to the expected ratio. 
following infection with a race that challenges $U r$-3. Several phenotypic and molecular traits suggest that two mutants may be siblings; therefore, we have characterized two in detail. These two mutants are clearly distinguished by their susceptibility response. One mutant, crg, produces grade 4 uredinia, which are distinct from the grade 5 uredinia of the second mutant, ur3- $\Delta 3$. These responses are in contrast to the HR response of Sierra, the progenitor genotype. Mutant ur3- $\Delta 3$ also exhibits delayed flowering and low seed set. By comparison, crg appears phenotypically more similar to Sierra.

Genetic analyses determined that each mutation was in a separate gene required for $U r-3$ resistance. For mutant ur3$\Delta 3$, the $U r-3 R$ gene itself is mutated. The phenotype of this mutation is similar (grade 5 to 6 uredinia) to other genotypes recessive at the $U r-3$. This contrasts with barley (Torp and Jøregensen 1986) and tomato (Hammond-Kosack et al. 1994; Salmeron et al. 1994) experiments that generated $R$ gene mutations expressing a range of phenotypic responses that were distinct from the "standard" susceptible phenotype.

The pathogenic response of the recently identified genes that complement $R$ genes varies. For those genes involved in fungal resistance, the mutant response can range from no asexual sporulation (tomato Rcr-1 and Rcr-2 [HammondKosack et al. 1994]) to a greater degree of asexual sporulation

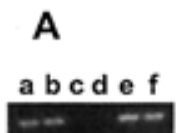

\section{B}

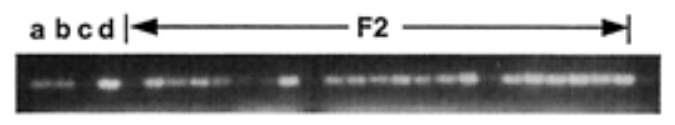

C

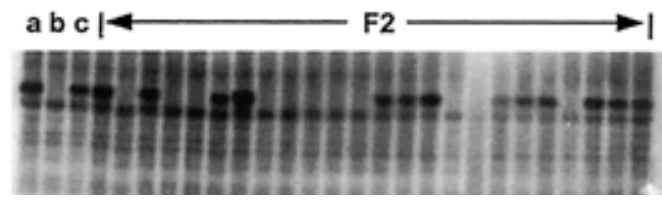

Fig. 1. Molecular analysis of common bean race 53 susceptible mutants and $F_{1}$ and $F_{2}$ progeny of the cross ur $3-\Delta 1 \times c v$. Sierra with polymerase chain reaction and hybridization probes to the common bean SB1 resistance gene analog (RGA) class. A, DNA from cvs. Sierra (a) and Olathe (b), mutant crg (c), and progeny of crg (d), ur3- $\Delta 2$ (e), and ur3- $\Delta 3$ (f) was amplified with primers specific to the SB1 RGA class. Primer annealing temperature was $60^{\circ} \mathrm{C}$. B, DNA of cvs. Olathe (a) and Sierra (b), mutant crg (c), the $F_{1}$ from the cross crg $\times$ Sierra (d), and $F_{2}$ progeny of the cross (lanes marked F2) was amplified with primers specific to the SB1 RGA class. Primer annealing temperature was $60^{\circ} \mathrm{C}$. All $\mathrm{F}_{2}$ progeny exhibiting the amplification fragment exhibited the hypersensitive resistance $(\mathrm{HR})$ response to bean rust race 53, and uredinia (grade $=5$ ) appeared on those $\mathrm{F}_{2}$ progeny lacking the amplification fragment. $\mathbf{C}$, DNA of cv. Sierra (a), mutant crg (b), the $F_{1}$ from the cross crg $\times$ Sierra (c), and $\mathrm{F}_{2}$ progeny of the cross (lanes marked $\mathrm{F} 2$ ) were digested with EcoRI and probed with the insert of the SB1 RGA clone. The final washing conditions were $0.1 \times \mathrm{SSC}(1 \times \mathrm{SSC}$ is $0.15 \mathrm{M} \mathrm{NaCl}$ plus $0.015 \mathrm{M}$ sodium citrate), $65^{\circ} \mathrm{C}$. Following infection with bean rust race 53, those $\mathrm{F}_{2}$ progeny exhibiting the HR response contained the diagnostic SB1 hybridizing upper restriction fragment, and those progeny exhibiting uredinia (grade $=4$ ) lacked this fragment. than observed with naturally susceptible genotypes (Arabidopsis EDS1 [Parker et al. 1996], tomato Prf [Salmeron et al. 1996]). Mutations of Arabidopsis NDRl (Century et al. 1995); PBS1, PBS2, and PBS3 (Warren et al. 1999); and barley Rar-1 and Rar-2 (Jøregensen 1988; Torp and Jøregensen 1986) result in a moderate degree of asexual sporulation that is less than observed in susceptible genotypes. Similarly, our analysis shows that, in comparison to a Ur-3-susceptible genotype such as Olathe, the crg mutant exhibits a reduced degree of sporulation. It remains to be determined whether the action of this gene is restricted to a single $U r$ locus or, as for the Arabidopsis genes EDS1 (Parker et al. 1996), NDR1 (Century et al. 1995), and PBS1, PBS2, and PBS3 (Warren et al. 1999), it interacts with the several $R$ gene loci that provide resistance to the various races of this pathogen. Further experimentation involving crosses of crg to genotypes carrying different $U r$ resistance loci will be necessary to determine if $\mathrm{Crg}$ is a critical component of bean rust resistance mediated by other $U r$ loci (Kelly et al. 1996).

The infection of mutants crg, ur3- $\Delta 1$, and other common bean genotypes homozygous recessive for the $u r-4, u r-6$, and ur-11 susceptibility alleles uncovered a unique effect of $\mathrm{Crg}$. For all genotypes, including crg, infections with race 67 produced grade 5 uredinia typical of genotypes containing the homozygous recessive at the $U r-11$ locus. In contrast, when challenged with either race 49 or 47 , crg produced distinctly smaller uredinia (grade 4) that those observed (grade 5) on other $u r-4$ and $u r-6$ genotypes. This raises the distinct possibility that $\mathrm{Crg}$, or another gene deleted from the mutant, acts as a positive host compatibility factor for the bean-bean rust interaction. The genetic analysis of Webster and Ainsworth (1988) supports the existence of such a gene in common bean. They demonstrated that a single dominant-acting gene conditions smaller bean rust uredinia size, and the recessive allele is responsible for larger uredinia. Our recessive mutant exhibited smaller uredinia size; therefore, the gene altered in crg would have the opposite allelic effect to the gene described by Webster and Ainsworth (1988). Genetic and molecular analyses of populations from crosses between crg and genotypes that exhibit varying susceptibility responses may provide further insight into this aspect of the bean-bean rust interaction.

The genetic analysis of crosses between the common bean genotypes Sierra (Ur-3 ur-6) and Olathe (ur-3 Ur-6) has pointed to other complementary factors controlling the response of common bean to the bean rust pathogen. When Sayler et al. (1995) challenged the $F_{1}$ plants with race 47 , a race for which $U r-6$ provides protection, the plants developed grade 3 uredinia rather than the expected grade 1 immune response of the Olathe parent. This suggests either an incompletely dominant gene action at the Ur-6 locus or that complementary genes from Sierra modified the phenotype of the $F_{1}$. The latter explanation appears to be correct because the $F_{2}$ plants segregated for a range of pathogenic responses (grades 1 to 6$)$ rather than just three grades $(1,3$, or 6$)$ that would be expected if incomplete dominance at $U r-6$ was controlling the compatibility phenotype.

That study (Sayler et al. 1995) also investigated the response of the same $\mathrm{F}_{2}$ population to race 55 , a race for which $U r-3$ provides protection. The $\mathrm{F}_{1}$ population expressed the grade 2 HR response of the Sierra parent, a result that confirms the dominant $\mathrm{HR}$ response. The $\mathrm{F}_{2}$ generation segregated into 
three classes: HR, immune (no observable hypersensitive lesions), and grade 6 uredinia. The segregation ratio of these three phenotypic classes $(9: 3: 4)$ demonstrated that a recessiveacting gene from Olathe was responsible for the immune response. Further analysis is necessary to determine if it is the same gene that conditions the immune response to race 47 . Collectively, these results demonstrate that genes other than the $R$ gene are required for a specific pathogenic response in common bean to the bean rust pathogen.

The conserved nature of the NBS in many plant $R$ genes (Baker et al. 1997) was used in PCR amplification, cloning, and sequencing experiments to isolate and characterize homologous fragments in soybean (Kanazin et al. 1996; Yu et al. 1996), potato (Leister et al. 1996), rice (Chen et al. 1998; Leister et al. 1998), barley (Chen et al. 1998; Leister et al. 1998; Seah et al. 1998), Arabidopsis (Aarts et al. 1998), corn (Collins et al. 1998), wheat (Chen et al. 1998; Seah et al. 1998), and lettuce (Shen et al. 1998). Collectively, these sequences are referred to as RGAs. Extensive sequence analysis indicates that, within a species, many of these RGAs can be considered paralogs. In each case, these RGA sequences were often found to map near disease resistance genes. The most compelling validation of this approach comes from the work in Arabidopsis in which one RGA was discovered to actually be a fragment of the previously cloned RPS5 gene (Warren et al. 1998).

Disease resistance genes are often clustered in plant genomes (Hulbert and Michelmore 1985; Islam and Shepard 1991; Saxena and Hooker 1968). As one might expect, RGAs are also clustered. Some of these RGAs cluster with known disease resistance genes (soybean [Kanazin et al. 1996; Yu et al. 1996], Arabidopsis [Aarts et al 1998], corn [Collins et al. 1998], and lettuce [Shen et al. 1998]). Meyers et al. (1998a) analyzed one cluster in lettuce and found that 24 members of the RGC2 RGA are distributed over a distance of $3.5 \mathrm{Mb}$. Located in this RGA-rich cluster is the Dm3 resistance gene. Detailed analysis of nine RGAs revealed that they encode NBS-LRR proteins (Meyers et al. 1998b). Surprisingly, this region appears to be devoid of genes other than those related to RGC2.

Rivkin et al. (1999) performed similar RGA-cloning experiments in common bean and discovered several families with sequence identities less than $52 \%$. One cluster of four RGAs mapped to linkage group $\mathrm{F}$ of the Florida molecular map. $\mathrm{SB} 1$, one RGA member of that cluster, is deleted in crg. The other RGAs of the cluster, however, are present in crg. Although the extent of the deletion has not been determined, we can conclude that the gene $\mathrm{Crg}$ does reside in the vicinity of other RGA sequences and is located on linkage group F. An intriguing question is whether or not $\mathrm{Crg}$ encodes a protein with an NBS sequence. Prf, a complementary gene required for Pseudomonas syringae pv. tomato resistance in tomato, encodes a protein that contains an NBS. Therefore, precedence exists for complementary genes to contain conserved domains found in $R$ proteins. Continued molecular analysis of $\mathrm{Crg}$ will allow us to address such interesting structural questions.

\section{MATERIALS AND METHODS}

Mutagenesis, mutant identification, and genetic analysis.

$\mathrm{M}_{1}$ plants derived from fast-neutron-bombarded seed (dosage level of 6.0-Gy; International Atomic Energy Agency, Vienna,
Austria) of the common bean cv. Sierra were selfed to produce $\mathrm{M}_{2}$ progeny. In all, 24,000 $\mathrm{M}_{2}$ plants were screened in the greenhouse with race 53 of the bean rust pathogen $U$. appendiculatus. Techniques for inoculum preparation and inoculation are as described in Sayler et al. (1995). The common bean cvs. Sierra, Olathe, and UI 114 (resistant, susceptible, and susceptible, respectively, to race 53) were included as checks. Susceptible $\mathrm{M}_{2}$ plants were selfed, and progeny challenged with race 53. Mutants crg and ur3- $\Delta 3$ were intermated and also crossed to Sierra and Olathe. $F_{1}$ and $F_{2}$ progeny plants were screened with race 53 and their pathogenic response scored.

\section{Response of mutants to multiple bean rust infection.}

Individual plants of Sierra, Olathe, and each mutant were inoculated with bean rust races $41(U r-3), 47(U r-6), 49$ (Ur4), $53(U r-3), 54(U r-3), 67(U r-11)$, and 108 (Ur-3) using the multiple inoculation procedure described by Stavely (1984a). The bean rust differential cvs. Aurora, Mex 235, and 51051 were included as checks.

\section{Molecular analysis.}

DNA was isolated from primary leaves according to the methods of Doyle and Doyle (1990). RAPD analysis of mutants and Sierra with 10-mer primers (Operon Technologies, Alameda, CA, U.S.A.) followed the procedures described in Brady et al. (1998). Amplification of each common bean RGA class used the primers and conditions described in Rivkin et al. (1999). Restriction enzyme digestion, blotting, hybridization, and washing were according to the methods of Rivkin et al. (1999).

\section{ACKNOWLEDGMENTS}

This research was supported by USDA/NRI grant 95-37300-1592. We thank B. Berzonsky, K. Grafton, and S. Kianian for critical review of this manuscript.

\section{LITERATURE CITED}

Aarts, M. G. M., Hekkert, B. L., Holub, E. B., Beynon, J. L., Stiekema, W. J., and Pereira, A. 1998. Identification of R-gene homologous DNA fragments genetically linked to disease resistance loci in Arabidopsis thaliana. Mol. Plant-Microbe Interact. 11:251-258.

Baker, B., Zambryski, P., Staskawicz, B., and Dinesh-Kumar, S. P. 1997. Signaling in plant-microbe interactions. Science 276:726-733.

Ballantyne, B. J. 1978. The genetic basis of resistance to rust, caused by Uromyces appendiculatus in bean (Phaseolus vulgaris). Ph.D. dissertation. University of Sydney, Sydney, Australia.

Brady, L., Bassett, M. J., and McClean, P. E. 1998. Molecular markers associated with $T$ and $Z$, two genes controlling partly colored seed coat patterns in common bean. Crop Sci. 38:1073-1075.

Carrington, J. C., Bisseling, T., Collmer, A., and Jones, J. D. G. 1999. Highlights from the Ninth International Congress on Molecular PlantMicrobe Interactions. Plant Cell 11:2063-2069.

Century, K. S., Holub, E. B., and Staskawicz, B. J. 1995. NDR1, a locus of Arabidopsis thaliana that is required for disease resistance to both a bacterial and a fungal pathogen. Proc. Natl. Acad. Sci. USA 92:6597-6601.

Century, K. S., Shapiro, A. D., Repetti, P. P., Dahlbeck, D., Holub, E., and Staskawicz, B. J. 1997. NDRI, a pathogen-induced component required for Arabidopsis disease resistance. Science 278:1963-1965.

Chen, X. M., Line, R. F., and Leung, H. 1998. Genome scanning for resistance-gene analogs in rice, barley, and wheat by high-resolution electrophoresis. Theor. Appl. Genet. 97:345-355.

Christ, B. J., and Groth, J. V. 1982. Inheritance of resistance in three cultivars of beans to the bean rust pathogen and the interaction of 
virulence and resistance genes. Phytopathology 72:771-773.

Collins, N. C., Webb, C. A., Seah, S., Ellis, J. G., Hulbert, S. H., and Pryor, A. 1998. The isolation and mapping of disease resistance analogs in maize. Mol. Plant-Microbe Interact. 11:968-978.

Doyle, J. J., and Doyle, J. L. 1990. Isolation of plant DNA from fresh tissue. Focus 12:13-15.

Falk, A., Feys, B. J., Frost, L. N., Jones, J. D. G., Daniels, M. J., and Parker, J. E. 1999. EDS1, an essential component of $R$ gene-mediated disease resistance in Arabidopsis has homology to eukaryotic lipases. Proc. Natl. Acad .Sci. USA 96:3202-3297.

Flor, H. H. 1956. The complementary genic systems in flax and flax rust. Adv. Genet. 8:29-54

Freialdenhoven, A., Scherag, B., Hollricher, K., Collinge, D. B., Thordal-Christensen, H., and Schulze-Lefert, P. 1996. Identification of genes required for the function of non-race specific mlo resistance to powdery mildew in barley. Plant Cell 8:5-14.

Glazebrook, J., Zook, M., Mert, F., Kagan, I., Rogers, E. E., Crute, I. R., Holub, E. B., Hammerschmidt, R., and Ausbel, F. M. 1997. Phytoalexin-deficient mutants of Arabidopsis reveal that PAD4 encodes a regulatory factor and that four $P A D$ genes contribute to downy mildew resistance. Genetics 146:381-392.

Grafton, K. F., Weiser, G. C., Litlefield, L. J., and Stavely, J. R. 1985. Inheritance of resistance to two races of leaf rust in edible bean. Crop Sci. 25:537-539.

Hammond-Kosack, K. E., Jones, D. A., and Jones, J. D. G. 1994. Identification of two genes required in tomato for full $C f-9$ dependent resistance to Cladisporiium fulvum. Plant Cell 6:361-374.

Hammond-Kosack, K. E., and Jones, J. D. G. 1996. Resistance genedependent plant defense responses. Plant Cell 8:1773-1791.

Hayes, H. K., Moore, M. B., and Stakman, E. C. 1939. Studies of inheritance in crosses between Bond, Avena byzantina and varieties of A. sativa. Minn. Agric. Exp. Stn. Tech. Bull. 137.

Hulbert, S. H., and Michelmore, R. W. 1985. Linkage analysis of genes for resistance to downy mildew (Bremia lactucae) in lettuce (Lactuca sativa). Theor. Appl. Genet. 70:520-528.

Islam, M. R., and Shepard, K. W. 1991. Present status of genetics of rust resistance genes in flax. Euhphytica 55:255-267.

Jøregensen, J. H. 1988. Genetic analysis of barley mutants with modifications of powdery mildew resistance gene $\mathrm{Ml}$-a12. Genome 30:129132.

Kanazin, V., Marek, L. F., and Shoemaker, R. C. 1996. Resistance gene analogs are conserved and clustered in soybean. Proc. Natl. Acad. Sci. USA 93:11746-11750.

Kehr, W. R., and Hayes, H. K. 1950. Studies of inheritance in crosses between Landhafer, Avena byzantina K., and two selections of $A$. sativa L. Agron. J. 42:71-78.

Kelly, J. D., Stavely, J. R., and Miklas, P. N. 1996. Proposed symbols for rust resistance genes. Annu. Rep. Bean Improv. Coop. 39:25-31.

Leister, D., Ballvora, A., Salamini, F., and Gebherdt, C. 1996. A PCR based approach for isolating pathogen resistance genes from potato with potential for wide application in plants. Nat. Genet. 14:421-429.

Leister, D., Kurth, J., Laurie, D. A., Yano, M., Sasaki, T., Devos, K., Graner, A., and Schulze-Lefert, P. 1998. Rapid reorganization of resistance gene homologues in cereal genomes. Proc. Natl. Acad. Sci. USA 95:370-375.

Meyers, B. C., Chin, D. B., Shen, K. A., Sivaramakrishnan, S., Lavelle, D. O., Zhang, Z., and Michelmore, R. W. 1998a. The major resistance gene cluster in lettuce is highly duplicated and spans several megabases. Plant Cell 10:1817-1832.

Meyers, B. C., Shen, K. A., Rohani, P., Gaut, B. S., and Michelmore, R. W. 1998b. Receptor-like genes in the major resistance locus of lettuce are subject to divergent selection. Plant Cell 10:1833-1846.

Parker, J. E., Holub, E. B., Frost, L. N., Falk, A., Gunn, N. D., and Daniels, M. J. 1996. Characterization of eds1, a mutation in Arabidopsis suppressing resistance to Peronospora parasitica specified by several different $R P P$ genes. Plant Cell 8:2033-2046.
Rivkin, M. I., Vallejos, C. E., and McClean, P. E. 1999. Diseaseresistance related sequences in common bean. Genome 42:41-47.

Salmeron, J. M., Barker, S. J., Carland, F. M., Mehta, A. Y., and Staskawicz, B. J. 1994. Two mutants altered in bacterial disease resistance provide evidence for a new locus controlling pathogen recognition. Plant Cell 6:511-520.

Salmeron, J. M., Oldroyd, G. E. D., Rommens, C. M. T., Scofield, S. R. Kim, H.-S., Lavelle, D. T., Dahlbeck, D., and Staskawicz, B. J. 1996. Tomato $\operatorname{Prf}$ is a member of the leucine-rice repeat class of plant disease resistance genes and lies embedded with the Pto kinase cluster. Cell 86:123-133.

Saxena, K. M. S., and Hooker, A. L. 1968. On the structure of a gene for disease resistance in maize. Proc. Natl. Acad. Sci. USA 61:1300-1305.

Sayler, R. J., Ewing, J. D., and McClean, P. E. 1995. Monogenic and epistatic resistance to bean rust infection in common bean. Physiol. Mol. Plant Pathol. 47:173-184.

Seah, S., Sivasithamparam, K., Karakousis, A., and Lagudah, E. S. 1998. Cloning and characterization of a family of disease resistance gene analogs from wheat and barley. Theor. Appl. Genet. 97:937-945.

Shen, K. A., Meyers, B. C., Nurul Islam-Faridi, M., Chin, D. B., Stelly, D. M., and Michelmore, R. W. 1998. Resistance gene candidates identified by PCR with degenerate oligonucleotide primers map to clusters of resistance genes in lettuce. Mol. Plant-Microbe Interact. 11:815-823.

Stavely, J. R. 1984a. Genetics of resistance to Uromyces phaseoli in a Phaseolus vulgaris line resistant to most races of the pathogen. Phytopathology 74:337-344.

Stavely, J. R. 1984b. Pathogenic specialization in Uromyces phaseoli in the United States and rust resistance in beans. Plant Dis. 68:95-99.

Stavely, J. R. 1998. Development of comprehensively rust resistant bean germplasm. (Abstr.) Phytopathology 88(suppl.):S85.

Stavely, J. R., Freytag, G. F, Steadman, J. R., and Schwartz, H. F. 1983. The 1983 bean rust workshop. Annu. Rep. Bean Improv. Coop. 26:iv-vi.

Stavely, J. R., Kelly, J. D., Grafton, K. F., Mullins, C. A., Straw, A., McMillarn, R. T., Jr., Beaver, J. S., Miklas, P. N., Steinke, J., Steadman, J. R., Coyne, D. P., Lindgren, D. T., and Silbernagel, M. J. 1997. Rust resistant bean germplasm releases, 1994-1996. Annu. Rep. Bean Improv. Coop. 40:120-121.

Stavely, J. R., Steadman, J. R., and McMillan, R. T. Jr. 1989. New pathogenic variability in Uromyces appendiculatus in North America. Plant Dis. 73:428-432.

Steadman, J. R., O'Keefe, D., Kerr, E. D., and Schwartz H. F. 1996. Pathogen variability in bean rust and implications for release of resistant cultivars on the US high plains. Annu. Rep. Bean Improv. Coop. 39:148-149.

Torp, J., and Jøregensen, J. H. 1986. Modification of powdery mildew resistance gene Mla-12 by induced mutation. Can. J. Genet. Cytol. 28:725-731.

Vennette, J. R., Gross, P. L., and Grafton, K. F. 1998. Bean rust in North Dakota. Annu. Rep. Bean Improv. Coop. 41:76-77.

Warren, R. F., Henk, A., Mowery, P., Holub, E., and Innes, R. W. 1998. A mutation within the leucine-rich repeat domain of the Arabidopsis disease resistance gene RPS5 partially suppresses multiple bacterial and downy mildew resistance gene. Plant Cell 10:1439-1452.

Warren, R. F., Merritt, P. M., Holub, E., and Innes, R. W. 1999. Identification of three putative signal transduction genes involved in $R$ genespecified disease resistance in Arabidopsis. Genetics 152:401-412.

Weetman, L. M. 1942. Genetic studies in oats of resistance to two physiologic races of crown rust. (Abstr.) Phytopathology 32:19.

Webster, D. M., and Ainsworth, P. M. 1988. Inheritance and stability of a small pustule reaction of snap beans to Uromyces appendiculatus. $\mathrm{J}$. Am. Soc. Hortic. Sci. 113:938-940.

Yu, Y. G., Buss, G. R., and Saghai-Maroof, M. A. 1996. Isolation of a superfamily of candidate disease-resistance genes in soybean based on a conserved nucleotide-binding site. Proc. Natl. Acad. Sci. USA 93:11751-11756. 